\title{
English Learning Practices
}

\section{Muhammad Arief Budiman ${ }^{1 *}$, Mei Fita Asri Untari ${ }^{2 *}$, Ikha Listyarini ${ }^{3 *}$ (D) 1,2,3 Universitas PGRI Semarang, Semarang, Indonesia}

\section{A R T I C L E I N F O}

Article history:

Received April 25, 2021

Revised April 27, 2021

Accepted June 17, 2021

Available online August 25, 2021

Kata Kunci:

pembelajaran, bahasa inggris, sekolah dasar

Keywords:

English, Learning, elementary school.

DOI:

http://dx.doi.org/10.23887/jpbi.v9i2. 39039

\section{A B S T R A C T}

\begin{abstract}
A B S T RAK
Belum siapnya sarana dan prasarana yang memadai sehingga pembelajaran tidak bisa berjalan dengan lancar. Tujuan penelitian ini adalah menganalisis proses pembelajaran bahasa inggris. Penelitian ini adalah penelitian kualitatif yaitu penelitian yang bersifat deskriptif dan cenderung menggunakan analisis, serta lebih menonjolkan proses dan makna. Pendekatan yang digunakan dalam penelitian ini adalah pendekatan fenemonelogi. Metode pengumpulan data yang digunakan dalam penelitian ini adalah wawancara, angket, dan observasi. Instrument yang digunakan untuk menganalsis data yaitu kuesioner. Teknik analisis data yang digunakan adalah analisis deskriptif kualitatif. Hasil penelitian ini yaitu terdapat empat factor penting yang mendukung kelancaran berjalanya proses pembelajaran Bahasa inggris: yaitu kepala sekolah, orang tua murid, peserta didik, dan pendidik. Peran kepala sekolah khususnya dukungan kepala sekolah berupa penyediaan sarana dan prasarana menjadi faktor penting karena tanpa adanya pembelajaran ini tidak akan dapat berjalan dengan lancar. Peran orang tua juga penting karena pendampingan mereka kepada siswa akan mampu memberikan suasana belajar. Motivasi siswa juga merupakan kunci penting keberhasilan pembelajaran bahasa Inggris. Penelitian ini dengan hasilnya ingin menunjukkan kepada berbagai pihak untuk memperhatikan empat factor utama demi kelancaran proses kegiatan belajar mengajar.
\end{abstract}

Adequate facilities and infrastructure are not yet ready so that learning cannot run smoothly. The purpose of this study was to analyze the process of learning English. This research is qualitative, descriptive research that tends to use analysis and emphasizes process and meaning more. The approach used in this study is phenomenological. Data collection methods used in this study were interviews, questionnaires, and observation. The instrument used to analyze the data is a questionnaire. The data analysis technique used is descriptive qualitative analysis. The results of this study are that four critical factors support the smooth running of the English learning process: the principal, parents of students, students, and educators. The role of the principal, especially the support of the principal in the form of providing facilities and infrastructure, is an essential factor because, without this learning, it will not be able to run smoothly. The role of parents is also essential because their assistance to students will be able to provide a learning atmosphere. Student motivation is also an essential key to the success of learning English. This research with the results wants to show that various parties pay attention to four main factors for the smooth teaching and learning activities process.

This is an open-access article under the CC BY-SA license. Copyright @ 2021 by Author. Published by Universitas Pendidikan Ganesha.

\section{INTRODUCTION}

Language teaching has developed in Indonesia in line with the community's need for the importance of language skills in the era of globalization (Prastikawati et al., 2021; Ratminingsih, 2018). As a solution to the community's needs, the government has provided a place in education to learn foreign languages (Annisa et al., 2018b; Effendi M., 2016). Language is the primary tool for communicating in human life, both for the benefit of individuals and the social environment (M. F. Fauzi et al., 2019; Hofmann \& Müller, 2021). Language is used as a tool to communicate between humans. The communication process will run well when both communicating parties are equipped with language and language skills (Arrosagaray et al., 2019; Başöz \& Çubukçu, 2014). Mastery of vocabulary and grammar are two aspects that must be mastered by someone who wants to learn a language, especially a foreign language (Hawkins, 2018; Mahmoudi et al., 2012). To actively communicate, the skills that students must master include speaking skills, listening skills, writing skills, and reading skills (Aguirre et al., 2016; O'Brien et al., 2020). This Indonesian language subject is in language skills which include oral and written language skills, both receptive (Mahmoudi et al., 2012; Sert \& Boynueğri, 2017). In a foreign language, one also needs to be equipped with knowledge of the culture of native speakers so as not to make cultural mistakes.

According to the Regulation of the Minister of Education and Culture of the Republic of Indonesia Number 81a of 2013 English language education at the elementary school level can be included in local content. Local content (muatan lokal) is study material or subjects in educational units that contain content and learning 
processes about local potential and uniqueness (Annisa et al., 2018a; Lestar, 2021). This is intended so that students form their understanding of excellence and wisdom in the area where they live. Thus learning at the elementary school level can be implemented by incorporating elements of local wisdom. For example, learning English with the theme of historical places located in the same city as the location of the elementary school (Saidah et al., 2021; Saraswati et al., 2020).

Many people regret the elimination of English language learning at the elementary school level. However, this does not rule out the possibility for decision-makers in each elementary school to find ways to incorporate English in their respective schools (Liyana \& Kurniawan, 2019; Pravitasari \& Yulianto, 2018). This is helped by the implementation of the 2013 curriculum in all elementary schools for those who are ready to implement it, both structurally and resource-ready (Sutarsyah, 2017; Sya \& Helmanto, 2020). In the 2013 curriculum, the school can include English subjects in elementary schools as local content. However, this is not implemented by all elementary schools. Many elementary schools abolish English subjects in their schools because they consider English subjects not mandatory subjects for their students (Maili, 2018; Surjono, 2016).

With a situation like the description above, many schools include English subjects in the realm of local content. This also happened at the Mojoagung 01 State Elementary School where Ms. Supaati as the principal and as a policymaker incorporated English subjects into the realm of local content. Ms. Supaati is of the opinion that her decision to include English subjects in the realm of local content is to provide basic knowledge as a basis for learning English at a further level. Another goal is to prepare students for the Olympics because the Olympics are held in English. His support as a school principal for the existence of English subjects is in the form of procuring English teachers and procuring English books in the school library. According to Mrs. Supaati, the procurement of English subjects at the Mojoagung 01 State Elementary School is in accordance with the school's vision and mission which states "in an effort to produce graduates who excel in achievement".

Learning English at SDN MOJOAGUNG 01 is trying to be carried out optimally. One of them is with the support of the principal who provides various adequate facilities for the comfortable learning of elementary school English. Another factor that also provides great support is the professionalism of the English teacher in carrying out English learning by choosing the right methods and media so that the learning atmosphere becomes interesting and students can participate in the teaching and learning process comfortably (Hawkins, 2018; Ho, 2020; Sert \& Boynueğri, 2017). The learning process will occur when there is an interaction or reciprocal relationship between students and their environment in an educational situation to achieve the goals that have been set (Nurlaily et al., 2019; Tjakradidjaja et al., 2016). The teacher is a determining factor for the success of a quality learning process. So that the success or failure of education in achieving its goals is always associated with the teacher (Parmin et al., 2015; Schildkamp et al., 2020). Therefore, efforts to improve the quality of education should start with improving the quality of teachers. The teacher as an educator does not only know about the material to be taught. Teachers must master the material taught by students so that students easily understand learning (Almutairi \& Shraid, 2021; Fun \& Maskat, 2010). With the description of the situation above, the researchers carried out research with the theme of English Learning Practice at Mojoagung 01 State Elementary School. This study aims to analyze the process of teaching and learning activities that occur in teaching English subjects.

\section{METHOD}

This research is phenomenological. Phenomenological research assumes that every individual experiences a phenomenon with his consciousness. In other words, the study of phenomenology aims to explore the most profound awareness of the subject of his experience in an event (Hasbiansyah, 2008). Data collection methods used in this study were interviews, questionnaires, and observation. Interviews were conducted with school principals and English teachers. Questionnaires were given to parents and students and conducted in January 2021 (2020/2021). The research location is SDN Mojoagung 01- Jalan Raya Pati Tayu km 14 ds Mojoagung. The technique used to analyze the data is descriptive qualitative analysis.

\section{RESULT AND DISCUSSION}

\section{Result}

The teaching process is a process carried out by a teacher in carrying out his role in the process of planned teaching and learning activities. To state that a teaching and learning process can be said to be successful, every teacher has their views in line with their philosophy. However, to equalize perceptions, we should be guided by the current curriculum that has been perfected. The teaching and learning strategy is the existence of teaching and learning interactions that are strategically planned to achieve special education goals in an appropriate (efficient) and effective manner. The term strategic is used based on the assumption that there are many choices of ways to 
learn to achieve goals. Therefore, the problem of compiling and planning teaching and learning programs is essentially a job of choosing various alternatives by considering their various strengths and weaknesses to achieve a goal. The success of a learning process cannot occur without the support of various parties. At SDN Mojoagung 01 there are four parties that involve, they are the principal, parents, students, and educators.

Implementation of English learning at SDN Mojoagung 01 is considered successful. This happened because of the support from various parties, one of which was the school principal, Mrs. Supaati. The teacher has served at SDN Mojoagung 01 for three years and during her assignment Teacher supported the existence of English subjects as local content. According to her, giving English lessons for students at SDN Mojoagung 01 is in accordance with the school's vision and mission, namely in an effort to produce graduates who excel in achievement. Although there is no infrastructure provided specifically for English subjects, the Teacher provides some support in the form of hiring an English teacher, as well as preparing reading books in the library about the English language. The teacher places English subjects in the realm of local content on the grounds of providing the basics of knowledge as the basis for learning English at a further level. The teacher also stated that English needs to be taught since elementary school so that children know it early, and prepare children for the Olympic competition because this competition uses English. The existence of English at SDN Mojoagung 01 also received support from parents, Suprihatini. The teacher stated her approval of the English subject at SDN Mojoagung 01. The teacher also stated that the existence of English subjects in elementary schools was important and the Teacher also stated that English needs to be taught from an early age for the future of her children. The teacher is happy that her son is getting English lessons, and the Teacher provides assistance in learning English to her children when the children have difficulties.

Some of the basic thoughts from parents about providing English language lessons as local content at SDN Mojoagung 01 are as follows: (1) Occupation: If we look at today's job vacancies, many list English language skills as one of the requirements that must be met, fulfilled. Especially for multinational companies and start-ups that are on the rise. This is because these companies need employees who are able to communicate with partners or customers who come from abroad. In addition, modern start-ups generally use a variety of advanced technologies that continue to develop, such as IT software, applications, and so on. As long as all these technologies still use English, all start-up employees who use them must be required to be able to speak English in order to be able to use, follow, and understand technological developments well. Therefore, by providing English subjects at SDN Mojoagung 01, it means that the school has prepared the future of the students well. (2) School/Higher education: For those who want to study abroad, learning English is a must, especially if the destination country uses English as the main language.

Moreover, almost all of the world's top universities are located in English-speaking countries such as the USA, UK, and so on. If students master English well, then their chances of being accepted at these universities will be wider. (3) Traveling: English is the most common language used by everyone on an international level. Almost everyone in the world learns English as a second language after their native language. That means, wherever students go, English is a common means of communication. By mastering it, traveling to any country will be easier and faster because it is not hindered by communication difficulties. In an era like today where many airlines offer budget flights and the tendency to intend to travel is increasing, learning English from an early age is the basic capital to prepare for traveling in the future. (4) Entertainment: The need for entertainment has become a basic need in this modern era. Of course, people have different tastes in entertainment. There are those who like TV, music, movies, social media, and others. if students master English, the choices of entertainment they can enjoy will be more diverse because they can enjoy not only local entertainment but also entertainment from abroad. Examples include foreign TV series, foreign influencer vlogs, foreign films, and so on. Indeed, we can use Indonesian subtitles to understand, but not all entertainment sources provide Indonesian subtitles. In addition, it would be better if we can enjoy the various entertainments in the original language. (5) Open Mind: Learning English can help children's minds to see from another point of view and express themselves. By having other communication channels to share their ideas and feelings, children will have many options for voicing their opinions. Studies show that mastering two languages will improve one's problem-solving and multitasking abilities. Thus, learning English from an early age is self-development for a better future.

The existence of English at SDN Mojoagung 01 also received support from students, Andicka Putra. He is happy with the existence of English subjects because according to him English lessons are not difficult subjects, and the material taught is also relatively easy (he stated that his favorite material is toys). He also stated that he was happy with the English teacher at SDN Mojoagung 01. He liked the teacher's way of teaching, and he also liked the teacher's patience in dealing with students. According to him, the experience of learning English with friends in the classroom is a pleasant experience. Although he does not use English outside of class, he gets help to learn English from his parents when he has difficulties. He hopes that the future English subjects will always be in a fun atmosphere and not boring. 
The main supporting factor for the success of the English teaching and learning process at SDN Mojoagung 01 is the professionalism and totality of the existing English teacher, Supriyadna Sari Puspita. The teacher is able to show her professionalism by combining her knowledge of elementary school studies and English language studies, as well as her 15 years of teaching experience. The teacher was able to do this because the Teacher was a double degree graduate (elementary school teacher education and English). The teacher supports and expresses her approval for the placement of English as a local content because it is in accordance with the curriculum and needs of elementary school students.

During her fifteen years of teaching, the Teacher stated that there are positive and negative sides to learning English in elementary schools. The positive side is the principal's support for the existence of English subjects. This is evidenced by the provision of adequate learning facilities and infrastructure (LCD and laptop). Another positive side comes from students where they show a high intensity and interest in English subjects. The negative side that the Teacher experienced was the psychological aspects of students who were up and down, sometimes students experienced boredom so that interest in taking lessons decreased or even did not exist at all, and they also stated that English is difficult. To overcome this Teacher provided a solution that was able to make the learning atmosphere fun again. The solution Teacher implemented was the use of learning media (videos, pictures, and games) as well as interesting and eye-catching teaching aids so that the interest of students increased again in participating in learning activities in class. Another solution is that Teacher provides material that interests students, namely material that connects learning with everyday life. The material provided also includes local wisdom, namely greeting words when meeting and entering class (simple expressions: good morning, how are you, etc). The material is given by her also adapts to thematic learning (eg grade six thematic about the solar system, then English material about planets and weather). The determinants of the success of the teaching and learning process include learning methods, learning media, learning models, learning approaches, educational technology, and evaluation.

In learning at SDN Mojoagung 01 English teacher Teacheruses audio-visual learning methods. The audiovisual learning method is a learning method that uses the help of audio-visual media so that learning activities involve hearing and sight at the same time (Yuliza, 2018). The teacher chose this method because it has several advantages, including: (1) it makes it easier for students to pronounce and remember vocabulary in English. (2) encourage students to be interested in practicing speaking, reading, and dialogue skills. The obstacle in using this method Teacher stated that some students remained silent. However, the Teacher gave a solution, which was to provide one-on-one encouragement to these students so that they finally wanted to be active in speaking in class.

In line with the method used, the teacher described that the Teacher used audio-visual learning media in learning English in elementary school. The teacher chose this learning media on the basis that students can observe and listen at the same time, and by using this media students understand new vocabulary more easily. The teacher said Teacher did not find any obstacles when applying this learning media in the classroom. Teacher chose to use a contextual learning model. In line with the learning model used, Teacher also described that the learning approach used was a contextual learning approach. Teacher implemented this approach on the basis that the learning materials became closer and easier for students to understand. In this approach Teacher takes learning material from students' daily lives so that students become more interested in learning. The application of this contextual approach does not experience obstacles in its implementation at SDN Mojoagung 01. To maximize the success of the learning process in the classroom, Teacher also utilizes educational technology (LCD and laptop) to support learning.

One element of learning is evaluation. Learning Evaluation is a process of determining the level of achievement of predetermined learning objectives in a systematic way. In terms of evaluation, Teacherused two types of tests, namely written tests, and oral tests. Teacher used written tests to determine student knowledge, while oral tests were used to determine student skills. According to her, these two types of tests have the advantage that it is easier to find out students' abilities. In applying these two types of tests Teacher did not experience any problems. In times of a pandemic like today, learning must continue. Many teachers implement online learning. The online learning system (on the network) is a learning system without face-to-face directly between teachers and students but is carried out online using the internet network (Umaya et al, 2020). Teachers must ensure that teaching and learning activities continue, even though students are at home. In this pandemic period, English learning at SDN Mojoagung 01 continues to take place using a combined offline and online method. According to teacher, this combined method is the right method to use during a pandemic like today. Teacher emphasized the importance of choosing the right learning method so that learning takes place safely and comfortably. Teacher explained that Teacher carried out online learning by sharing material through YouTube videos and giving assignments through group chats on the WhatsApp application. However, this has an obstacle, namely not all students actively participate. To overcome this, Teacher implemented a solution in the form of offline class procurement. In the process of learning English, other obstacles come from students and parents. Students said that they could not directly ask the teacher. Meanwhile, the students' parents stated that they had difficulty guiding the learning of English that they did not understand. 


\section{Discussion}

The principal as a leader plays a role in making learning activities achieve learning objectives through good learning activities (Ariyanti, 2020; Ratmini et al., 2019). In addition to fostering teachers in the process of educating and teaching, school principals foster personal, professional, and social relationships with the school community (Suriansyah \& Aslamiah, 2015; Umi et al., 2019). An element that is no less important in a learning process is the participation and support of parents (Lau \& Li, 2019; López et al., 2021). Parental support is an awareness of the responsibility to educate and nurture children continuously by providing assistance by parents to children to meet children's basic needs in the form of giving attention, feeling safe and comfortable, and feeling affection (Creed et al., 2012; Dong et al., 2020).

The next supporting element so that the learning process can run well are students. Students are a human component that occupies a central position in the teaching and learning process. In the teaching and learning process, students as parties who want to achieve goals, have goals, and then want to achieve them optimally (Arsy et al., 2020; Hendriana et al., 2018). Teachers have a responsibility to shape students. A teacher is an educator of a certain science, or can also be referred to as a professional educator with the main task of educating, teaching, guiding, directing, training, assessing, and evaluating students (Chen \& Tsai, 2021; Chien \& Hui, 2010). A professional teacher is a teacher who knows about himself where he is a person who is called to assist students in learning (Potvin et al., 2021; Wagiran et al., 2019). Professional teachers are teachers who are aware that they are required to find out continuously how students should learn. The main supporting factor for the success of the teaching and learning process is the teacher (Mailizar et al., 2020; Rusdin, 2018).

Learning Media is anything that can be used to convey messages or information in the teaching and learning process so that it can stimulate students' attention and interest in learning (Manuaba, 2017; Suaeb et al., 2018). Audio-visual learning media are intermediary media whose absorption is through sight and hearing to build conditions that can make students able to acquire knowledge, skills, or attitudes that are used to help achieve learning goals (H. A. Fauzi et al., 2017; Michelsanti et al., 2019). The advantages of using audio-visual media are Clarify the presentation of the message; Overcoming space limitations; Concepts that are too broad can be visualized in the form of films, frame films, and pictures; Audiovisual media plays a role in tutorial learning, the use of media is not boring and the results are easier to understand (Michelsanti et al., 2019).

The contextual learning model is an educational process that aims to motivate students to understand the meaning of the subject matter being studied by linking the material to the context of their daily lives (personal, social, and cultural contexts) so that students have knowledge/skills that can be flexibly applied (transferred) from one problem/context to another (Anugraheni et al., 2018; Rahayu \& Febriaty, 2017). The advantages of the contextual approach are Provide opportunities for students to be able to move forward in accordance with the potential of students so that students are actively involved in the teaching and learning process (Hobri et al., 2018; Susiloningsih, 2016). (a) students can think critically and creatively in collecting data, understand an issue and solve problems and teachers can be more creative. (c) Make students aware of what they are learning. (d) The selection of information based on student needs is not determined by the teacher. $€$ Learning is more fun and less boring. (f) Help students work effectively in groups. She chose this learning model because according to her this learning model was more in line with the circumstances of the students at SDN Mojoagung 01. When using this contextual learning model in the classroom, she stated that the participants were more focused from the beginning of the lesson to the end. She also stated that she did not encounter any problems at all when applying this contextual learning model (Gitriani et al., 2018; Liston \& Geary, 2015).

A contextual learning approach is a learning approach that emphasizes the full involvement of students to be able to find the material being studied and relate it to real-life situations to encourage students to be able to apply it in their lives (Selvianiresa \& Prabawanto, 2017; Tapingkae et al., 2020). In the learning process, teachers are required to create very interesting learning, one of which is by utilizing information technology that can attract students' attention (Yerizon et al., 2020). Learning by utilizing information technology is indeed inseparable from our lives today, almost everyone in their activities or activities always uses information technology devices, as well as in the learning process at this time almost all teachers use information technology in the learning process, but not many teachers can make the learning media itself interesting (Mutakinati et al., 2018)(Hermawan et al., 2013). The use of information technology in the classroom according to Teacheris able to make students get the experience of seeing and listening to the material directly. According to her, information technology has the advantage of making it easier for students to understand the material. She stated that she did not find any obstacles in utilizing information technology in classroom learning. 


\section{CONCLUSION}

It was found that four important factors that support the success of learning English in elementary schools at SDN Mojoagung 01 are: the role of the principal, the role of parents of students, the motivation of students, and the professionalism of the teacher. The role of the principal, especially the support of the principal in the form of providing facilities and infrastructure, is an important factor because without this learning will not be able to run smoothly. The role of parents is also important because their assistance to students will be able to provide an adequate learning atmosphere not only within the school but also outside the school. The motivation of students is also an important key to the success of learning English where learning will not succeed if students are in a psychologically burdened condition.

\section{REFERENCES}

Aguirre, D., Bustinza, D., \& Garvich, M. (2016). Influence of Songs in Primary School Students' Motivation for Learning English in Lima, Peru. English Language Teaching, 9(2), 178. https://doi.org/10.5539/elt.v9n2p178

Almutairi, T. S., \& Shraid, N. S. (2021). Teacher evaluation by different internal evaluators: Head of departments, teachers themselves, peers and students. International Journal of Evaluation and Research in Education, 10(2), 588-596. https://doi.org/10.11591/ijere.v10i2.20838

Annisa, N., Saragih, A. H., \& Mursid. (2018a). Pengembangan Media Pembelajaran Interaktif Pada Mata Pelajaran Bahasa Inggris. Jurnal Teknologi Informasi Dan Komunikasi Dalam Pendidikan, 5(2). https://doi.org/10.24114/jtikp.v5i2.12599

Annisa, N., Saragih, A. H., \& Mursid, R. (2018b). Pengembangan Media Pembelajaran Interaktif Pada Mata Pelajaran Bahasa Inggris. Jurnal Teknologi Informasi Dan Komunikasi Dalam Pendidikan, 5(2). https://doi.org/10.24114/jtikp.v5i2.12599

Anugraheni, A. D., Oetomo, D., \& Santosa, S. (2018). Pengaruh Model Discovery Learning dengan Pendekatan Contextual Teaching Learning terhadap Keterampilan Argumentasi Tertulis Ditinjau dari Kemampuan Akademik Siswa SMAN Karangpandan The Effect of Discovery Learning Model with Contextual Teaching Learning A. Bioedukasi, 11(2), 123-128. https://doi.org/10.20961/bioedukasi-uns.v11i2.24914

Ariyanti, Y. (2020). Keterampilan Manajerial Kepala Sekolah dalam Meningkatkan Kinerja Guru. AKSES: Jurnal Ekonomi Dan Bisnis, 14(1), 26-35. https://doi.org/10.31942/akses.v14i1.3265

Arrosagaray, M., González-Peiteado, M., Pino-Juste, M., \& Rodríguez-López, B. (2019). A comparative study of Spanish adult students' attitudes to ICT in classroom, blended and distance language learning modes. Computers and Education, 134(October 2018), 31-40. https://doi.org/10.1016/j.compedu.2019.01.016

Arsy, H. I., Prasetyo, A. P. B., \& Subali, B. (2020). Predict-Observe-Explain Strategy with Group Investigation Effect on Students ' Critical Thinking Skills and Learning Achievement. Journal of Primary Education, 9(1), 75-83. https://doi.org/10.15294/jpe.v9i1.29109

Başöz, T., \& Çubukçu, F. (2014). Pre-service EFL Teacher's Attitudes towards Computer Assisted Language Learning (CALL). Procedia - Social and Behavioral Sciences, 115. https://doi.org/10.1016/j.sbspro.2014.01.253

Chen, C.-H., \& Tsai, C.-C. (2021). In-service teachers' conceptions of mobile technology-integrated instruction: Tendency towards student-centered learning. Computers \& Education, 170(1). https://doi.org/10.1016/j.compedu.2021.104224

Chien, C., \& Hui, A. N. N. (2010). Creativity in early childhood education: Teachers' perceptions in three Chinese societies. Thinking Skills and Creativity, 5(2). https://doi.org/10.1016/j.tsc.2010.02.002

Creed, P. A., Conlon, E. G., \& Zimmer-Gembeck, M. J. (2012). Career barriers and reading ability as correlates of career aspirations and expectations of parents and their children. Journal of Vocational Behavior, 70(2). https://doi.org/10.1016/j.jvb.2006.11.001

Dong, C., Cao, S., \& Li, H. (2020). Young children's online learning during COVID-19 pandemic: Chinese parents' beliefs and attitudes. Children and Youth Services Review, 118(June), 105440. https://doi.org/10.1016/j.childyouth.2020.105440

Effendi M. (2016). Penerapan Lesson Study dalam Meningkatkan Kemampuan Mengajar Guru Bahasa Inggris pada Madrasah Tsanawiyah Negeri Model Sorong. Journal of Islamic Education, 1(2). https://doi.org/10.30984/j.v1i2.430

Fauzi, H. A., Komalasari, K., \& Malik, Y. (2017). Utilization of Audio Visual Media to Improve Student Learning Result in IPS Learning. International Journal Pedagogy of Social Studies, 2(1), 88-103. https://doi.org/10.17509/ijposs.v2i1.8666

Fauzi, M. F., Buhun, M. F., \& Purwadi, A. (2019). The Influence of Teams Games Tournament (TGT) toward Students' Interest in Arabic Language Learning. Journal Of Arabic Languange Teaching, Linguistic and 
Literate, 2(2). https://doi.org/10.22219/jiz.v2i2.9986

Fun, C. S., \& Maskat, N. (2010). Teacher-Centered Mind Mapping vs Student-Centered Mind Mapping in the Teaching of Accounting at Pre-U Level - An Action Research. International Conference on Learner Diversity, 240. https://doi.org/10.1016/j.sbspro.2010.10.034

Gitriani, R., Aisah, S., Hendriana, H., \& Herdiman, I. (2018). Pengembangan Lembar Kerja Siswa Berbasis Pendekatan Kontekstual pada Materi Lingkaran Untuk Siswa SMP. Jurnal Review Pembelajaran Matematika, 3(1), 40-48. https://doi.org/10.15642/jrpm.2018.3.1.40-48

Hasbiansyah. (2008). Pendekatan fenomenologi: Pengantar praktik penelitian dalam Ilmu Sosial dan Komunikasi. Mediator: Jurnal Komunikasi, 9(1). https://doi.org/10.29313/mediator.v9i1.1146

Hawkins, M. W. (2018). Self-directed learning as related to learning strategies, self-regulation, and autonomy in an English language program: A local application with global implications. Studies in Second Language Learning and Teaching, 8(2), 445-469. https://doi.org/10.14746/ssllt.2018.8.2.12

Hendriana, H., Johanto, T., \& Sumarmo, U. (2018). The role of problem-based learning to improve students' mathematical problem-solving ability and self confidence. Journal on Mathematics Education, 9(2), 291299. https://doi.org/10.22342/jme.9.2.5394.291-300

Hermawan, I. P. E., Jampel, I. N., \& Widiana, I. W. (2013). Pengaruh Pembelajaran Pendekatan Contextual Teaching And Learning (CTL) Berbasis Kearifan Lokal Terhadap Hasil Belajar Ips Siswa Kelas IV SD. Mimbar PGSD Undiksha, 1(1). https://doi.org/10.23887/jjpgsd.v1i1.844

Ho, Y.-Y. C. (2020). Communicative language teaching and English as a foreign language undergraduates' communicative competence in Tourism English. Journal of Hospitality, Leisure, Sport \& Tourism Education, 27. https://doi.org/10.1016/j.jhlste.2020.100271

Hobri, Septiawati, I., \& Prihandoko, A. C. (2018). High-order thinking skill in contextual teaching and learning of mathematics based on lesson study for learning community. International Journal of Engineering and Technology(UAE), 7(3), 1576-1580. https://doi.org/10.14419/ijet.v7i3.12110

Hofmann, V., \& Müller, C. M. (2021). Language skills and social contact among students with intellectual disabilities in special needs schools. Learning, Culture and Social Interaction, 30. https://doi.org/10.1016/j.lcsi.2021.100534

Lau, M. M., \& Li, H. (2019). Whole-day or half-day kindergarten? Chinese parents' perceptions, needs, and decisions in a privatised marketplace. Children and Youth Services Review, 105. https://doi.org/10.1016/j.childyouth.2019.104427

Lestar, W. (2021). Pengembangan Modul Pembelajaran Bahasa Inggris Berbasis Andragogi Pada Program Studi Pendidikan Biologi di Universitas Muhammadiyah Palembang. Edunesia: Jurnal Ilmiah Pendidikan, 2(1), 171-177. https://doi.org/10.51276/edu.v2i1.114

Liston, J., \& Geary, T. (2015). Evaluating a Guidance Counsellor Education Programme: The Methodological Complexities. Procedia - Social and Behavioral Sciences, 191(0), 1014-1018. https://doi.org/10.1016/j.sbspro.2015.04.650

Liyana, A., \& Kurniawan, M. (2019). Speaking Pyramid sebagai Media Pembelajaran Kosa Kata Bahasa Inggris Anak Usia 5-6 Tahun. Jurnal Obsesi: Journal of Early Childhood Education, 3(1). https://doi.org/10.31004/obsesi.v3i1.178

López, K. M. J. de, Feilberg, J., Baena, S., Lyons, R., \& Lyons, R. (2021). "So, I told him to look for friends!" Barriers and protecting factors that may facilitate inclusion for children with Language Disorder in everyday social settings: Cross-cultural qualitative interviews with parents. Research in Developmental Disabilities, 115. https://doi.org/10.1016/j.ridd.2021.103963

Mahmoudi, E., Samad, A. bt A., \& Razak, N. Z. B. A. (2012). Attitude and Students' Performance in Computer Assisted English Language Learning (CAELL) for Learning Vocabulary. Procedia - Social and Behavioral Sciences, 66. https://doi.org/10.1016/j.sbspro.2012.11.293

Maili, S. N. (2018). Bahasa Inggris pada sekolah dasar: Mengapa perlu dan mengapa dipersoalkan. JUDIKA (Jurnal Pendidikan Unsika), 6(1). https://journal.unsika.ac.id/index.php/judika/article/view/1203

Mailizar, M., Almanthari, A., Maulina, S., \& Bruce, S. (2020). Secondary School Mathematics Teachers' Views on E-learning Implementation Barriers during the COVID-19 Pandemic: The Case of Indonesia. Eurasia Journal of Mathematics, Science and Technology Education, 16(7), em1860. https://doi.org/10.29333/ejmste/8240

Manuaba, I. B. S. (2017). Pengaruh Model Problem Based Learning Berbantuan Media Audio Visual Terhadap Penguasaan Kompetensi Ips. MIMBAR PGSD Undiksha, 5(2), 1-8. https://doi.org/10.23887/jjpgsd.v5i2.11000

Michelsanti, D., Tan, Z.-H., Sigurdsson, S., \& Jensen, J. (2019). Deep-learning-based audio-visual speech enhancement in presence of Lombard effect. Speech Communication, 115. 
https://doi.org/10.1016/j.specom.2019.10.006

Mutakinati, L., Anwari, I., \& Yoshisuke, K. (2018). Analysis of students' critical thinking skill of middle school through stem education project-based learning. Jurnal Pendidikan IPA Indonesia, 7(1), 54-65. https://doi.org/10.15294/jpii.v7i1.10495

Nurlaily, V. A., Soegiyanto, H., \& Usodo, B. (2019). Elementary school teacher's obstacles in the implementation of problem-based learning model in mathematics learning. Journal on Mathematics Education, 10(2), 229238. https://doi.org/10.22342/jme.10.2.5386.229-238

O'Brien, B. A., Chin, S., \& Chin, S. (2020). The structure of home literacy environment and its relation to emergent English literacy skills in the multilingual context of Singapore. Early Childhood Research Quarterly, 53. https://doi.org/10.1016/j.ecresq.2020.05.014

Parmin, Sajidan, Ashadi, \& Sutikno. (2015). Skill of prospective teacher in integrating the concept of science with local wisdom model. Jurnal Pendidikan IPA Indonesia, 4(2), 120-126. https://doi.org/10.15294/jpii.v4i2.4179

Potvin, A. S., Boardman, A. G., \& Stamatis, K. (2021). Consequential change: Teachers scale project-based learning in English language arts. Teaching and Teacher Education, 107. https://doi.org/10.1016/j.tate.2021.103469

Prastikawati, E. F., Wiyaka, W., \& Budiman, T. C. S. (2021). Pelatihan Penyusunan Soal Bahasa Inggris Berbasis HOTS bagi Guru Bahasa Inggris SMP. Jurnal Pengabdian Masyarakat, 6(1). https://doi.org/10.30653/002.202161.761

Pravitasari, S. G., \& Yulianto, M. L. (2018). Penggunaan Multimedia Interaktif Dalam Pembelajaran Bahasa Inggris (Studi Kasus Di SDN 3 Tarubasan Klaten). Profesi Pendidikan Dasar, 1(1), 37. https://doi.org/10.23917/ppd.v1i1.3825

Rahayu, S. E., \& Febriaty, H. (2017). Penerapan Model Pembelajaran Contextual Teaching And Learning (CTL) Untuk Meningkatkan Pemahaman Materi Pasar Valuta Asing Pada Mata Kuliah Ekonomi Internasional 2 (Studi Mahasiswa Semester 5 Jurusan Ekonomi Pembangunan Fakultas Ekonomi UMSU). Jurnal Ilmiah Manajemen Dan Bisnis, 17(2), 94-107. https://doi.org/10.30596/jimb.v17i2.960

Ratmini, N. A., Natajaya, I. N., \& Sunu, I. G. K. A. (2019). Kontribusi Gaya Kepemimpinan Kepala Sekolah, Komitmen Organisasi, Iklim Kerja dan Motivasi Kerja Terhadap Kinerja Guru SMP Negeri 2 Singaraja. Jurnal Administrasi Pendidikan Indonesia, 10(2), 91-100. https://doi.org/10.23887/japi.v10i2.2795

Ratminingsih, N. M. (2018). Implementasi Board Games Dan Pengaruhnya Terhadap Hasil Belajar Bahasa Inggris. Jurnal Ilmu Pendidikan, 24(1), 19. https://doi.org/10.17977/um048v24i1p19-28

Rusdin, N. M. (2018). Teachers' Readiness in Implementing 21st Century Learning. International Journal of Academic Research in Business and Social Sciences, 8(4), 1271-1284. https://doi.org/10.6007/IJARBSS/v8i4/4270

Saidah, A., Budiman, M. A., \& Wijayanti, A. (2021). Analisis Pelaksanaan Pendidikan Karakter Dalam Pembelajaran Bahasa Inggris Siswa Kelas IV SD Bilingual Muhammadiyah 1 Purwodadi. Wawasan Pendidikan, 1(2). https://doi.org/10.26877/wp.v1i2.8723

Saraswati, W., Budiman, M. A., \& Rahmawati, I. (2020). Pembelajaran Bahasa Inggris Di SD Negeri Petompon 01 Semarang. Jurnal Sekolah, 4(4). https://doi.org/10.24114/js.v4i4.20616

Schildkamp, K., Kleij, van der, Heitink, Kippers, W. B., \& Veldkamp, B. P. (2020). Formative assessment: A systematic review of critical teacher prerequisites for classroom practice. International Journal of Educational Research. https://doi.org/10.1016/j.ijer.2020.101602

Selvianiresa, D., \& Prabawanto, S. (2017). Contextual Teaching and Learning Approach of Mathematics in Primary Schools. Journal of Physics: Conference Series, 895(1). https://doi.org/10.1088/17426596/895/1/012171

Sert, N., \& Boynueğri, E. (2017). Digital technology use by the students and english teachers and self-directed language learning. World Journal on Educational Technology: Current Issues, 9(1), 24. https://doi.org/10.18844/wjet.v9i1.993

Suaeb, S., Degeng, I. N. S., \& Amirudin, A. (2018). Meningkatkan Hasil Belajar IPS Siswa Kelas V melalui Penerapan Pembelajaran Kooperatif Model Teams Games Tournament ( TGT ) Berbantuan Media Tebak Gambar. Jurnal Pendidikan: Teori, Penelitian, Dan Pengembangan, 3(1), 146-154. https://doi.org/10.17977/jptpp.v3i1.10435

Suriansyah, \& Aslamiah. (2015). Strategi Kepemimpinan Kepala Sekolah, Guru, Orang Tua, Dan Masyarakat Dalam Membentuk Karakter Siswa. Cakrawala Pendidikan, 34(2). https://journal.uny.ac.id/index.php/cp/article/view/4828/4180

Surjono, J. (2016). Pengembangan Multimedia Pembelajaran Bahasa Inggris Untuk Pembelajaran Teks Recount Di Mtsn II Yogyakarta. Jurnal Inovasi Teknologi Pendidikan, 3(1), 25-39. https://doi.org/10.21831/tp.v3i1.8287

Susiloningsih, W. (2016). Model Pembelajaran CTL (Contextual Teaching and Learning) dalam Meningkatkan 
Hasil Belajar Mahasiswa PGSD Pada MataKuliah Konsep IPS Dasar. PEDAGOGIA: Jurnal Pendidikan, 5(1), 57. https://doi.org/10.21070/pedagogia.v5i1.89

Sutarsyah, C. (2017). Pembelajaran bahasa Inggris sebagai muatan lokal pada sekolah dasar di propinsi Lampung. AKSARA: Jurnal Bahasa Dan Sastra, http://jurnal.fkip.unila.ac.id/index.php/aksara/article/view/12633

Sya, M. F., \& Helmanto, F. (2020). Pemerataan Pembelajaran Muatan Lokal Bahasa Inggris Sekolah Dasar Indonesia. Jurnal Pendidikan Guru Sekolah Dasar, 7(1). https://doi.org/10.30997/dt.v7i1.2348

Tapingkae, P., Panjaburee, P., Hwang, G.-J., \& Srisawasdi, N. (2020). Effects of a formative assessment-based contextual gaming approach on students' digital citizenship behaviours, learning motivations, and perceptions. Computers \& Education, 159. https://doi.org/10.1016/j.compedu.2020.103998

Tjakradidjaja, F. A., Prabandari, Y. S., Prihatiningsih, T. S., \& Harsono, H. (2016). The role of teacher in medical student self-directed learning process. Journal of Education and Learning (EduLearn), 10(1), 78-84. https://doi.org/10.11591/edulearn.v10i1.2992

Umi, R., Nopriansyah, U., \& Purnama, S. (2019). Korelasi kepemimpinan kepala taman kanak-kanak terhadap kinerja kompetensi pedagogik dan kompetensi profesional guru. Al-Athfaal: Jurnal Ilmiah Pendidikan Anak Usia Dini. https://doi.org/10.24042/ajipaud.v2i1.4552

Wagiran, Pardjono, Suyanto, W., Sofyan, H., Soenarto, S., \& Yudantoko, A. (2019). Competencies of Future Vocational Teachers: Perspective of in-Service Teachers and Educational Experts. Cakrawala Pendidikan, 38(2), 388-400. https://doi.org/10.21831/cp.v38i2.25393

Yerizon, Y., Putri, Y. U., Musdi, E., \& Permana, D. (2020). Efektivitas Perangkat Pembelajaran Matematika Berbasis Pendekatan Contextual Teaching and Learning Terhadap Kemampuan Komunikasi Matematis. AKSIOMA: Jurnal Program Studi Pendidikan Matematika, 9(1), 205. https://doi.org/10.24127/ajpm.v9i1.2305 